\title{
Peran Motor Listrik pada Transportasi Ramah Lingkungan
}

\author{
Slamet Riyadi \\ Teknik Elektro Unika Soegijapranata Semarang \\ email : riyadi@unika.ac.id ; s_riyadi672003@yahoo.com
}

\begin{abstract}
The fossil based fuel crisis and environmental degradation issues have caused the transportation system to use electric motors as an alternative to combustion engines. The emergence of electric hybrid vehicles and electric vehicles has been a sign that the revolution in the field of transportation has reached the implementation stage. DC motors that are capable to generate large torque becomes an option at first, but due to its limitations then other types of motors which have advantages such as DC motor but eliminating the its weakness are developed. BLDC (Brushless Direct Current) motors and switched reluctance motors are priority in implementation. This paper describes the characteristics and performance of the three motors which can be used as the background for developing environmentally friendly transportation system.
\end{abstract}

Keywords: DC motor, BLDC, reluctance, converter, electric vehicle, hybrid

\begin{abstract}
Abstrak
Krisis bahan bakar fossil dan issu kerusakan lingkungan telah mendorong sektor transportasi untuk menggunakan penggerak motor listrik sebagai alternatif pengganti motor bakar. Munculnya kendaraan hibrid listrik (Hybrid Electric Vehicle) dan kendaraan listrik (Electric Vehicle) menjadi pertanda bahwa revolusi dalam bidang transportasi telah sampai pada tahap implementasi. Motor DC dengan torka besar menjadi pilihan pada awalnya, tetapi karena keterbatasan maka dikembangkan motor jenis lain yang memiliki kelebihan seperti motor DC tetapi mengeliminasi kelemahannya. Motor BLDC (Brushless Direct Current) dan motor switched reluctance menjadi prioritas dalam implementasi. Pada makalah ini dipaparkan karakteristik dan kinerja ketiga motor tersebut yang dapat digunakan sebagai dasar untuk mengembangkan sistem transportasi ramah lingkungan.
\end{abstract}

Kata kunci: motor DC, BLDC, reluctance, konverter, kendaraan listrik, hybrid

\section{PENDAHULUAN}

Transportasi menjadi sektor utama yang mendukung pertumbuhan perekonomian suatu negara. Munculnya issu lingkungan dan krisis energi berbasis fossil telah mendorong berkembangnya transportasi ramah lingkungan. Motor bakar sebagai penggerak kendaraan konvensional menjadi pemicu munculnya polusi dan pemakai bahan bakar fossil. Penggerak kendaraan berbasis listrik telah dikembangkan untuk menggantikan motor bakar ataupun bekerja secara bersamaan, kendaraan tersebut dikenal dengan kendaraan listrik atau electric vehicle dan kendaraan hibrid listrik atau hybrid 
electric vehicle (Emadi dkk, 2008), (Sanz dkk, 2018).

Suatu motor listrik mampu mengubah energi listrik menjadi energi mekanik melalui media elektromagnet, motor listrik inilah yang menjadi penggerak pada sistem transportasi ramah lingkungan. Motor listrik arus searah (motor DC) mampu menghasilkan torka besar dan mudah diatur kecepatannya tetapi karena penggunaan sikat dan komutator maka motor ini memerlukan perawatan berkala. Berbeda dengan motor tersebut, motor arus bolak balik (motor AC jenis induksi) tidak memerlukan perawatan dan harganya relatif murah tetapi torka yang dihasilkan kecil. Aplikasi motor listrik untuk sistem transportasi harus memenuhi kriteria : memiliki torka besar dan mudah diatur kecepatannya (Hughes, 2006), (Yedamale, 2002), (Condit, 2010).

Mengacu pada keuntungan motor DC maka dikembangkan motor DC tanpa sikat (BLDC), yaitu dengan membuat rotor dari magnet permanen dan menempatkan belitan pada stator. Dengan bantuan konverter statis dan kendali digital maka motor jenis ini mampu dikendalikan kecepatannya dengan tetap menunjukkan unjuk kerja yang baik. Keterbatasan motor BLDC terletak pada magnet permanen sehingga sulit dibuat untuk rating besar
(Yedamale, 2003), (Rodriguez and Emadi, 2007), (Shao, 2006). Perkembangan lanjut dari motor listrik adalah dengan menghilangkan magnet permanen pada rotor dan mengganti dengan laminasi bahan feromagnet, motor jenis ini bekerja dengan dasar gejala reluktansi sehingga dikenal dengan motor switched reluctance (SRM). Untuk operasinya motor SRM memerlukan konverter statis dan kendali digital (Arefeen, 1998), (Mahmoud dkk, 2013), (Dong, 2013), (Jain and Mohan, 2005).

Pemahaman dan penguasaan teknologi motor listrik beserta kendali menjadi penting dalam mengembangkan sistem transportasi yang ramah lingkungan. Oleh karena itu pada makalah ini dipaparkan analisis dasar dari motor DC, motor BLDC dan motor SRM. Guna mendukung analisis maka dilakukan simulasi dan pengujian laboratorium untuk motor BLDC dan motor SRM sebagai pengembangan motor DC.

\section{MOTOR LISTRIK}

Motor listrik merupakan piranti yang mampu mengubah energi listrik menjadi energi mekanik, umumnya pengubahan terjadi melalui media elektromagnet. Dalam perkembangannya dikenal 
beberapa jenis motor listrik mulai dari motor DC, motor AC hingga motor modern yang memerlukan dukungan elektronika daya.

\subsection{Motor Arus Searah (Motor DC)}

Motor DC memiliki torka besar dan pengaturan kecepatan yang mudah sebagai keunggulan tetapi adanya sikat dan komutator menjadi kelemahan, selain itu motor DC harganya mahal dan memerlukan perawatan berkala. Secara konstruksi motor DC memiliki stator berupa magnet permanen atau belitan medan sedangkan bagian rotor terdiri dari belitan jangkar yang ujung-ujungnya terhubung dengan komutator. Jika belitan medan dan belitan jangkar memiliki sumber tegangan secara terpisah maka motor DC ini dikatakan berpenguatan terpisah, sedangkan jika kedua belitan memiliki satu sumber maka dikategorikan motor DC penguatan sendiri. Hubungan secara seri antara belitan medan dan belitan jangkar akan membentuk motor DC seri sedangkan jika keduanya dihubungkan secara paralel akan membentuk motor DC shunt.

Pada Gambar-1 ditunjukkan rangkaian ekuivalen motor DC dengan induktansi rotor $\mathrm{L}_{\mathrm{a}}$, resistansi rotor $\mathrm{R}_{\mathrm{a}}$, tegangan $\mathrm{EMF}$ $\mathrm{E}_{\mathrm{a}}$, tegangan terminal $\mathrm{V}_{\mathrm{t}}$, induktansi stator $L_{f}$ dan resistansi stator $R_{f}$. Pengaturan kecepatan motor DC dapat dilakukan dengan menggunakan persamaan di bawah ini

$$
\omega_{r}=\frac{V_{t}-I_{a} R_{a}}{K_{1} I_{f}}
$$

di mana

$$
\begin{array}{ll}
\omega_{r} & =\operatorname{kecepatan} \operatorname{rotor}(\mathrm{RPM}) \\
I_{a} & =\operatorname{arus} \text { jangkar }(\mathrm{A}) \\
I_{f} & =\operatorname{arus} \text { medan }(\mathrm{A})
\end{array}
$$

Pengaturan kecepatan motor DC dapat dilakukan dengan dua cara, yaitu dengan mengubah nilai tegangan terminal yang dilakukan pada daerah constant torque atau dengan mengubah arus medan pada daerah constant power (Gambar-3). Pengaturan kecepatan yang umum dilakukan adalah dengan mengubah nilai tegangan terminal. Pada Gambar-4 disajikan skema pengaturan tersebut melalui implementasi konverter DC-DC yang akan mengubah tegangan DC konstan menjadi tegangan DC variabel sesuai dengan kecepatan yang diinginkan.

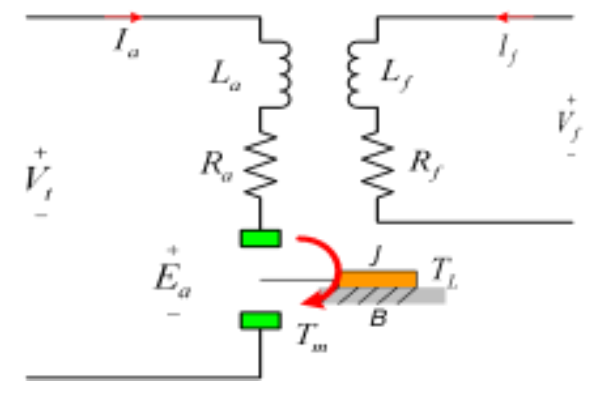

Gambar 1

Skema motor DC penguatan terpisah (Riyadi, 2009) 


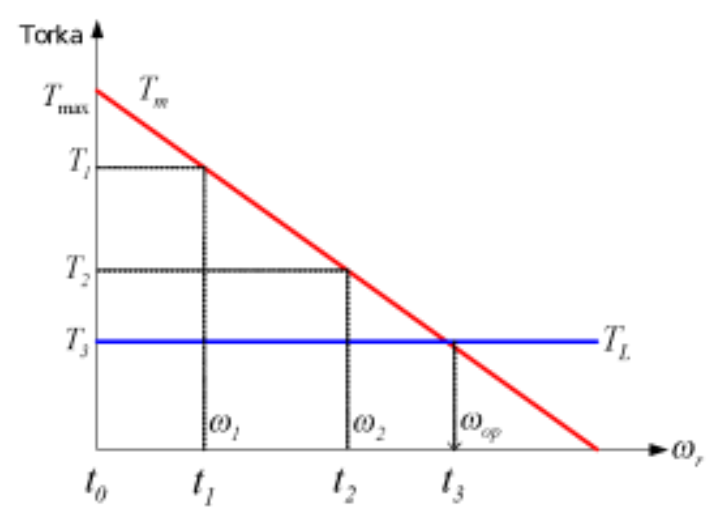

Gambar 2

Karakteristik motor DC penguatan terpisah

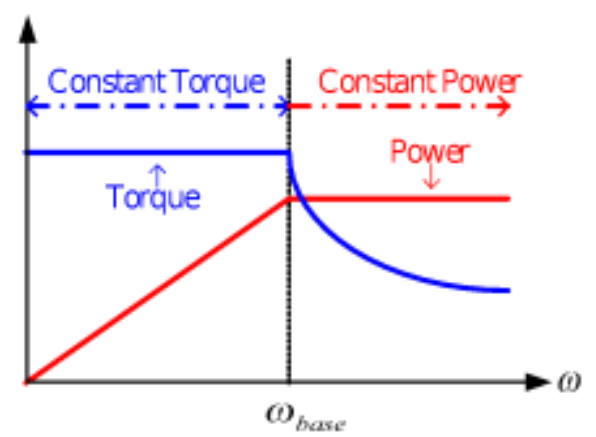

Gambar 3

Daerah pengaturan kecepatan motor DC

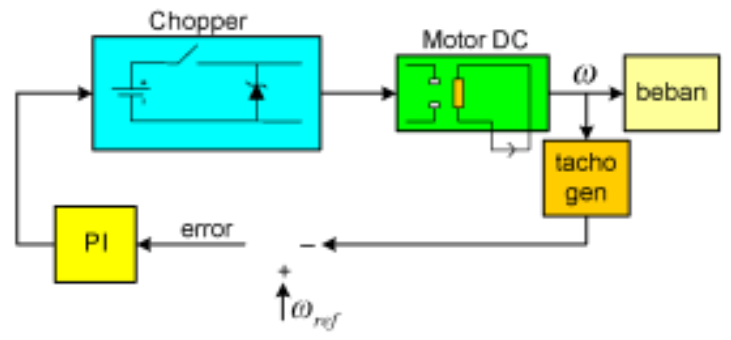

Gambar 4

Blok pengaturan kecepatan motor DC (Riyadi, 2009)

\subsection{Motor DC Tanpa Sikat (Brushless DC Motor)}

Motor DC memiliki kelemahan karena adanya sikat dan komutator. Berkembangnya teknologi elektronika daya dan digital telah mendorong bagaimana menghilangkan kekurangan motor DC yaitu melalui penggunaan rangkaian elektronik pengganti sikatkomutator, motor ini selanjutnya dikenal dengan motor DC tanpa sikat (Brushless DC Motor = BLDC). Motor jenis BLDC memiliki struktur stator berupa belitan dan rotor terdiri dari magnet permanen. Karakteristik motor BLDC memiliki kesamaan dengan karakteristik motor DC penguatan terpisah

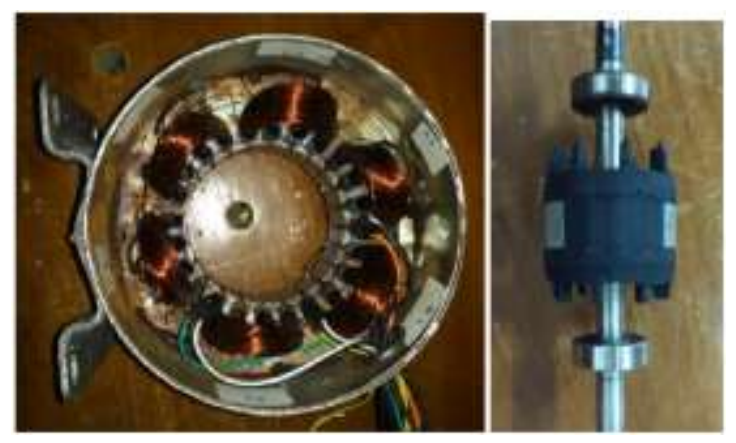

Gambar 5 Struktur motor jenis BLDC

Belitan stator dari motor BLDC akan menghasilkan kutub magnet utara atau selatan bergantung polaritas arus yang ditentukan posisi rotor, oleh karena itu informasi posisi rotor diperlukan. Dalam aplikasi untuk mendapatkan informsi posisi rotor dapat dilakukan dengan dua cara, yaitu dengan memakai sensor (misalkan hall-effect sensor) dan tanpa 
menggunakan sensor melalui deteksi fluksi, tegangan balik atau cara lain (sensorless). Persamaan torka motor BLDC disajikan dengan

$$
\begin{aligned}
& T_{e}=K_{T}\left[f\left(\theta_{e}\right) \cdot i_{a}+f\left(\theta_{e}-\frac{2 \pi}{3}\right) \cdot i_{b}\right. \\
& \left.+f\left(\theta_{e}+\frac{2 \pi}{3}\right) \cdot i_{c}\right]
\end{aligned}
$$

di mana

$$
\begin{aligned}
& T_{e}: \text { torka } \\
& I_{a}, I_{b}, I_{c}: \text { arus fasa } \\
& F(\theta): \text { sudut fasata } \\
& K_{t}: \text { konstan }
\end{aligned}
$$

Karakteristik dari motor BLDC ditunjukkan pada Gambar-6.

Pada Gambar-7 disajikan skema bagaimana mengoperasikan motor BLDC tiga fasa (6 kutub stator dan 4 kutub rotor) melalui konverter tiga fasa. Untuk mengirimkan arus listrik dari sumber tegangan DC diperlukan konverter dengan tiga lengan yang berisi enam buah saklar statis. Dalam setiap saat diupayakan terdapat dua saklar selalu konduksi dengan ketentuan satu saklar bagian atas dan satu saklar bagian bawah dari lengan berbeda.

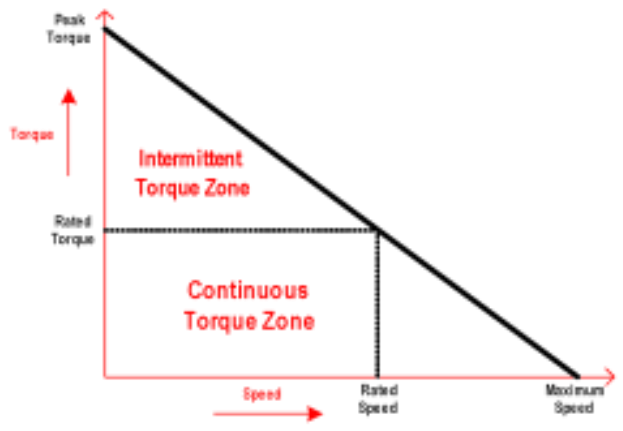

Gambar 6

Karakteristik motor BLDC

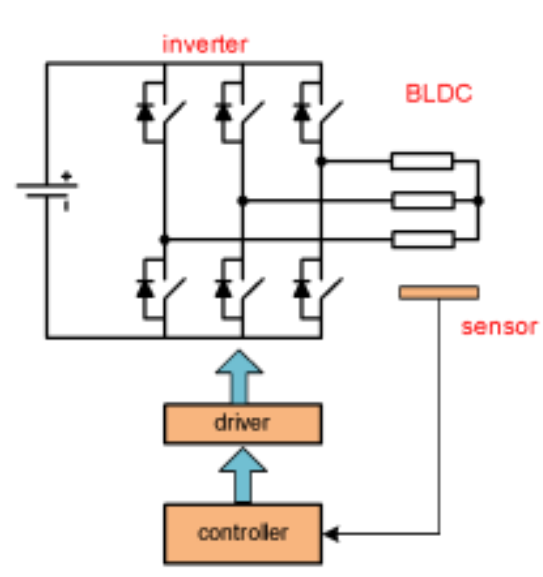

Gambar 7

Skema pengaturan kecepatan motor BLDC

\subsection{Motor Switched Reluctance (SRM)}

Motor Switched Reluctance (SRM) sebenarnya sudah dikenal sejak akhir abad 19 tetapi masih dalam rancangan yang sederhana. Selama beberapa dekade perkembangan SRM ini tidak mengalami kemajuan sehingga secara praktis tidak banyak dijumpai dalam aplikasi. Dengan berkembangnya teknologi semikonduktor dan kendali digital, SRM mulai mendapat perhatian untuk dikembangkan. Bahkan dewasa ini di mana isu tentang "green 
energy" mulai diterapkan, motor jenis SRM banyak diteliti dan dikembangkan.

Motor SRM merupakan mesin listrik yang mengubah torka reluktansi menjadi daya mekanik. Jumlah kutub stator dan kutub rotor dari SRM biasanya tidak sama untuk menghindari kondisi di mana tidak dihasilkan torka awal yaitu kondisi di mana seluruh kutub rotor berada pada kondisi segaris terhadap kutub stator. Torka SRM dibangkitkan atas dasar kecenderungan kutub rotor untuk sejajar (segaris) dengan kutub stator yang tereksitasi. Prinsip ini mengacu pada perbedaan reluktansi fluksi magnet antara posisi rotor yang segaris dan tak segaris ketika stator tereksitasi. Kondisi ini selanjutnya mengakibatkan dihasilkannya torka yang menarik rotor menuju posisi segaris.

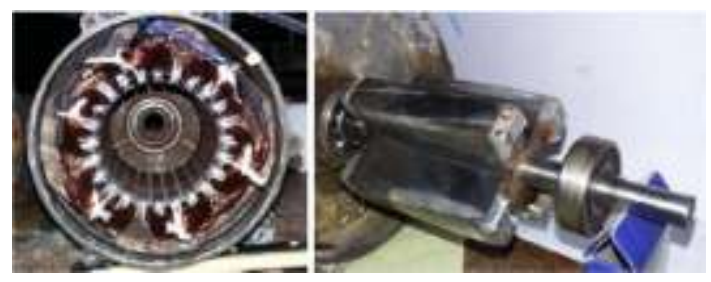

\section{Gambar 8}

Konstruksi motor switched reluctance

Karakteristik torka terhadap kecepatan dari motor SRM ditunjukkan pada Gambar9.

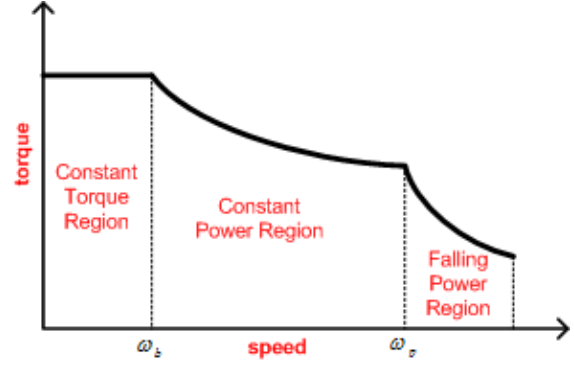

\section{Gambar 9 \\ Karakteristik motor SRM}

Torka SRM (T) dapat dinyatakan sebagai hubungan antara arus stator (i) dan perubahan induktansi stator (L) terhadap posisi rotor $(\mathrm{l})$

$$
T=\frac{1}{2} i^{2} \frac{d L(\theta)}{d \theta}
$$

\section{KONVERTER}

Konverter statis merupakan suatu perangkat yang mampu mengubah besaran listrik menjadi besaran listrik lainnya dengan menggunakan saklar statis. Suatu saklar statis mampu melakukan pensaklaran dengan kecepatan sangat tinggi, dalam implementasi dapat digunakan MOSFET atau IGBT.

\subsection{Konverter untuk Motor BLDC}

Motor BLDC memiliki stator berupa belitan untuk menghasilkan medan magnet. Masing-masing kutub stator harus mampu menghasilkan medan magnet utara $(\mathrm{N})$ atau selatan (S) bergantung polaritas arus. Pada stator motor BLDC 
tiga fasa yang terhubung bintang (Y) maka dibuat sedemikian dua kutub stator selalu bekerja dengan satu kutub $\mathrm{N}$ dan satu kutub S. Dengan mengasumsikan jika arus masuk dari belitan A menuju belitan $\mathrm{C}$ maka kutub stator fasa-A akan menghasilkan medan magnet utara $(\mathrm{N})$ dan kutub stator fasa-C akan menghasilkan medan magnet selatan (S)

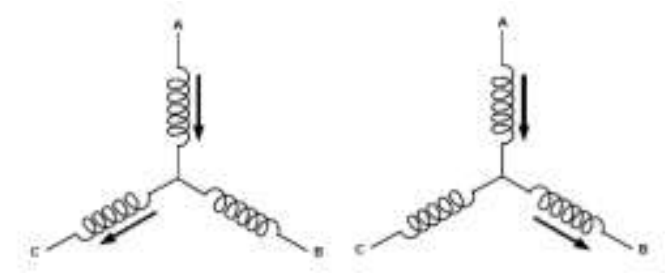

Gambar 10

Aliran arus pada stator motor BLDC (a) arus dari belitan fasa-A menuju fasa-C (b) arus dari belitan fasa-A menuju fasa-B

Suatu konverter diperlukan agar polaritas arus pada motor BLDC dapat dikendalikan secara sekuensial. Dengan mengatur saklar yang hidup dan mati dari konverter maka kutub-kutub magnet stator dapat dikendalikan sesuai dengan keinginan. Setiap saat hanya ada dua buah saklar yang konduksi sehingga hanya ada dua fasa stator yang menjadi magnet kutub utara $(\mathrm{N})$ dan kutub selatan $(\mathrm{S})$.

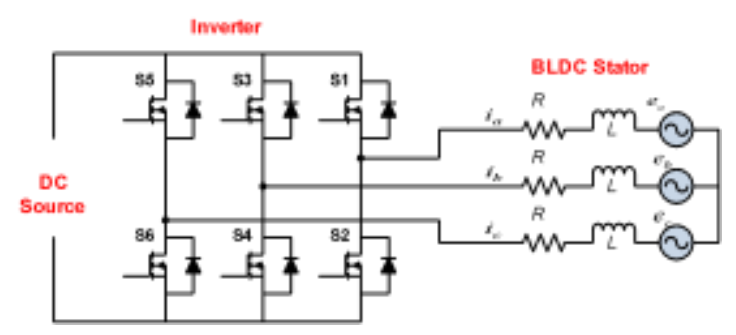

\section{Gambar 11}

Konverter penggerak motor BLDC

\subsection{Konverter untuk Motor Switched}

\section{Reluctance}

Berbagai topologi konverter dikembangkan untuk aplikasi motor SRM, tetapi jenis asymmetric lebih unggul secara kinerja. Konverter jenis ini memiliki dua saklar statis dan dua dioda untuk tiap fasa nya (Gambar-12), karena tiap belitan fasa stator terhubung ke sumber tegangan DC melalui dua buah saklar maka rugi akibat jatuh tegangan pada saklar akan cukup signifikan untuk aplikasi pada tegangan rendah. Di sisi lain, konverter ini memiliki keunggulan yaitu pengontrolan fasa dapat dilakukan secara bebas tidak dipengaruhi fasa lain walaupun jumlah saklar keseluruhan lebih banyak. Mode operasi pada konverter ini ada tiga meliputi : magnetizing, demagnetizing dan freewheeling. Pada mode magnetizing, proses pemberian eksitasi untuk belitan fasa-A dilakukan dengan menyalakan saklar $\mathrm{S}_{1}$ dan $\mathrm{S}_{2}$. Pada kondisi ini tegangan belitan fasa-A akan sebesar tegangan masukan $\mathrm{V}_{\mathrm{dc}}$ yang akan menghasilkan torka positif jika diberikan saat induktansi fasa-A meningkat. Saat posisi rotor dan stator segaris (induktansi 
maksimum) maka arus stator harus dimatikan, proses komutasi dapat dilakukan dengan menggunakan mode freewheeling, dilakukan dengan menyalakan salah satu saklar, misalkan saklar $S_{1}$ saja atau $S_{2}$ saja untuk fasa-A. Pada kondisi ini tegangan belitan fasa-A sama dengan nol sehingga arus akan berangsur turun dan akan menghasilkan torka negatif. Untuk mengurangi torka negatif maka arus harus dimatikan dengan cepat melalui mode demagnetizing, yaitu dengan mematikan kedua saklar (saklar $S_{1}$ dan $S_{2}$ untuk memadamkan fasa-A).

Dalam aplikasi, umumnya SRM dioperasikan untuk kecepatan yang dapat diubah, cara yang digunakan mengatur kecepatan motor SRM adalah dengan mengatur arus melalui pengaturan tegangan. Strategi modulasi lebar pulsa (PWM) umumnya digunakan untuk pengaturan kecepatan motor ini, saklarsaklar bagian atas dari konverter difungsikan untuk membentuk fungsi PWM sementara saklar-saklar bagian bawah difungsikan untuk komutasi.

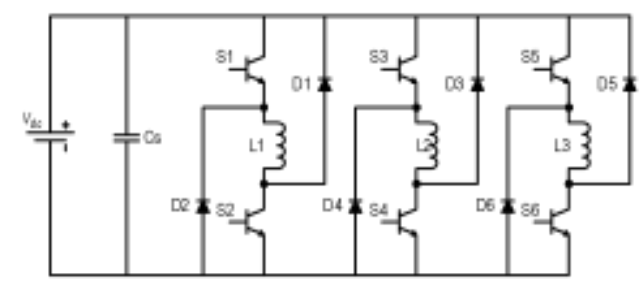

Gambar 12

Konverter asymmetric penggerak motor BLDC

\section{HASIL DAN DISKUSI}

Guna mendukung kajian di atas maka dilakukan simulasi dengan menggunakan perangkat lunak PSIM. Simulasi dilakukan pada motor BLDC dengan menggunakan konverter standar tiga fasa dan motor SRM dengan menggunakan konverter asymmetric. Gambar-13 dan Gambar-14 menunjukkan hasil simulasi untuk motor BLDC, hubungan daya dan kecepatan menunjukkan bahwa pada saat awal pengasutan motor diperlukan daya lebih besar karena untuk mengantisipasi momen kelembaman rotor (Gambar-13). Sedangkan bentuk gelombang arus ditentukan oleh tegangannya. Arus tidak hanya memiliki polaritas positif dan negatif, tetapi juga nol. Kondisi ini disebabkan setiap fasa akan dua kali konduksi dan sekali padam untuk setiap siklus.

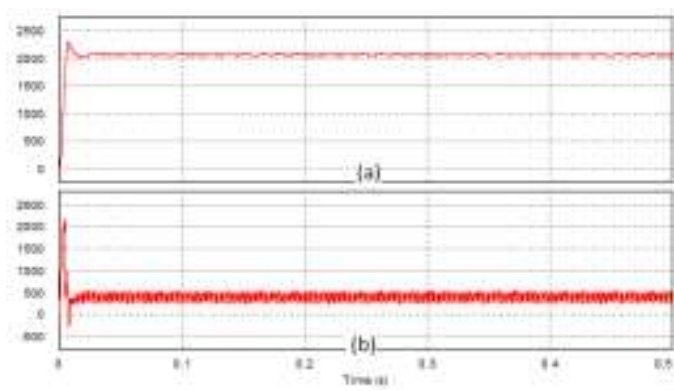

Gambar 13

Hasil simulasi motor BLDC dengan tegangan DC-link inverter sebesar $100 \mathrm{~V}$ 
dan duty cycle sebesar 0,8 (a) kecepatan motor (b) daya rata-rata diserap motor

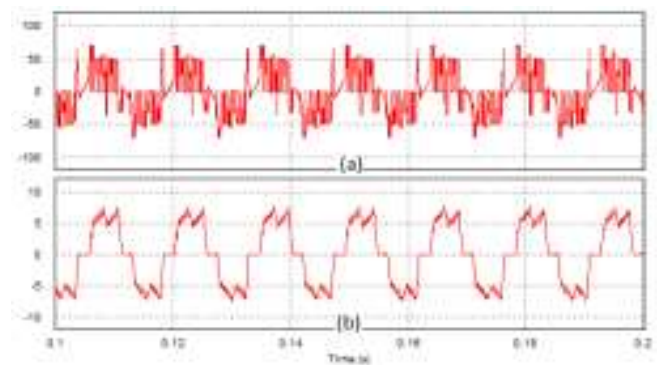

Gambar 14

Hasil simulasi motor BLDC dengan tegangan DC-link inverter sebesar $100 \mathrm{~V}$ dan duty cycle sebesar 0,8 (a) tegangan fasa motor (b) arus fasa motor

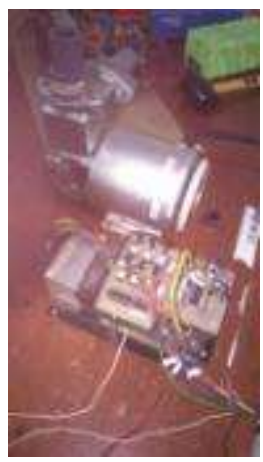

Gambar 15

Prototip untuk pengujian motor BLDC

Pengujian dilakukan dengan menggunakan prototip (Gambar-15) serta hasil pengujian ditunjukkan pada Gambar-16 dan Gambar17. Bentuk gelombang pengujian menunjukkan kesesuaian dengan hasil simulasi.

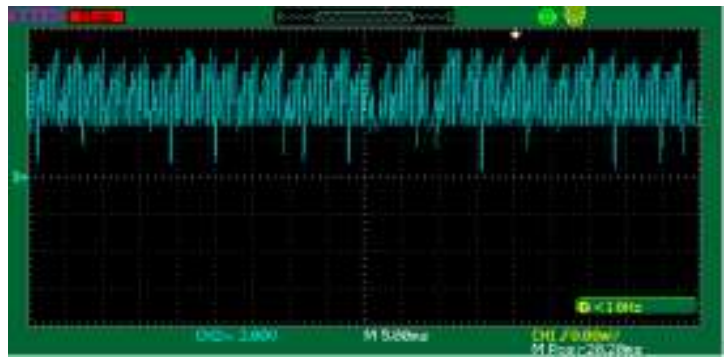

Gambar 16

Hasil pengujian arus DC-link dari inverter sebagai penggerak motor BLDC [skala arus 2 A/div]

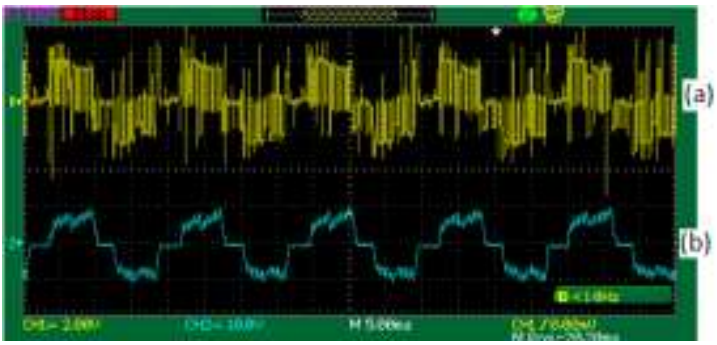

Gambar 17

Hasil pengujian inverter sebagai penggerak motor BLDC (a) tegangan fasa-a (b) arus fasa-a [skala arus $10 \mathrm{~A} / \mathrm{div}$ - skala tegangan $20 \mathrm{~V} / \mathrm{div}$

Hasil simulasi untuk motor SRM disajikan pada Gambar-18 dan Gambar19. Pada saat awal diperlukan daya besar karena untuk membangkitkan torka yang besar (Gambar-18). Gelombang tegangan memiliki pola positif saat awal arus mengalir dan tegangan polaritas negatif saat pemadaman arus, kondisi ini ditujukan agar dihasilkan efisiensi yang tinggi.

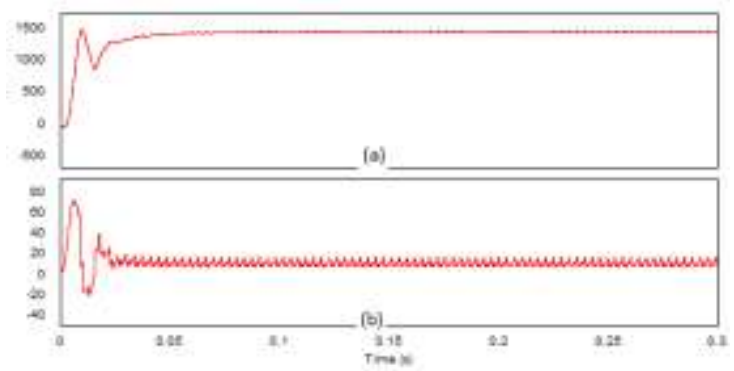

Gambar 18

Hasil simulasi motor SRM

(a) kecepatan (b) torka 


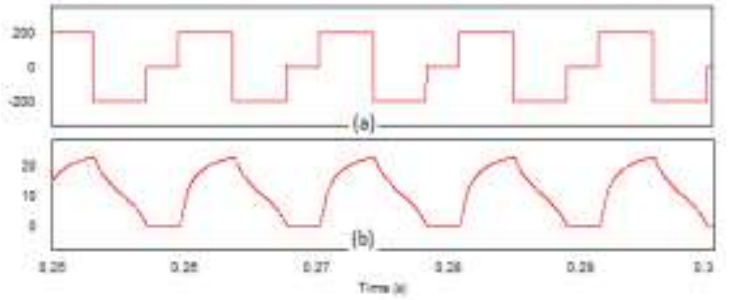

Gambar 19

Hasil simulasi motor SRM

(a) tegangan fasa-a (b) arus fasa-a

Pengujian dilakukan dengan menggunakan prototip (Gambar-20) serta hasil pengujian ditunjukkan pada Gambar-21 dan Gambar23.

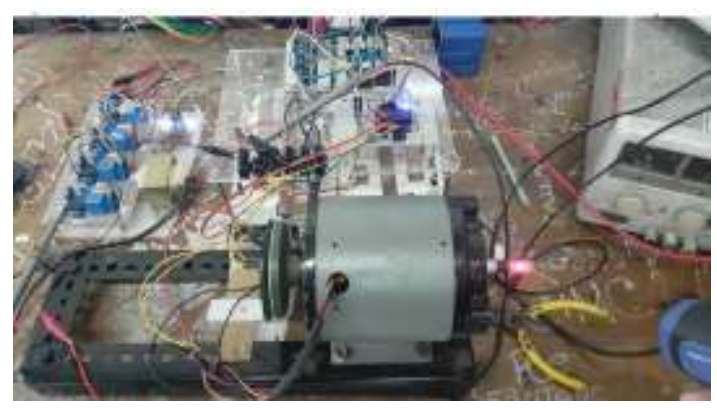

\section{Gambar 20}

Prototip untuk pengujian motor SRM

Bentuk gelombang pengujian menunjukkan bahwa tegangan masing-masing fasa tergeser 120 derajad begitu juga arus fasanya. Untuk memadamkan arus digunakan tegangan sumber dengan polaritas terbalik.

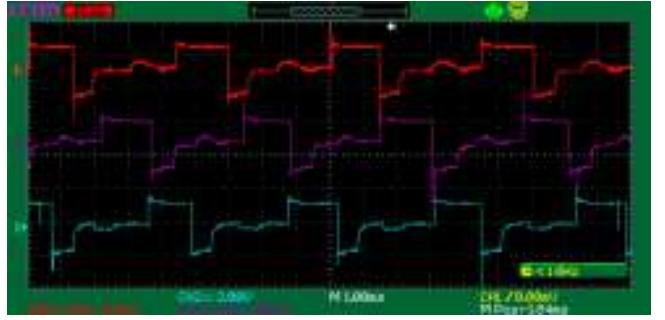

Gambar 21

Hasil pengujian tegangan fasa motor SRM

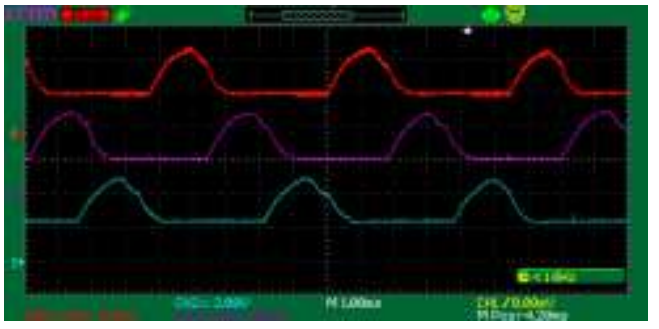

Gambar 22

Hasil pengujian arus fasa motor SRM

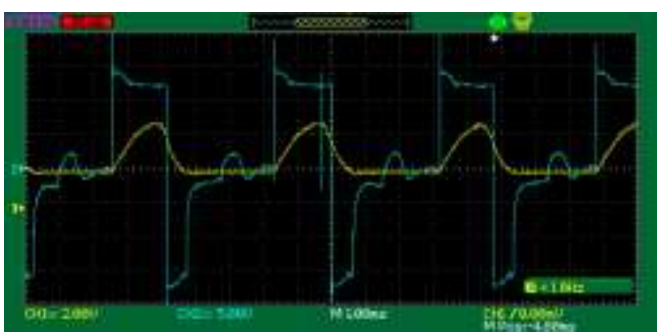

Gambar 23

Hasil pengujian motor SRM

(a) tegangan fasa-a (b) arus fasa-a

\section{KESIMPULAN}

Kajian tentang motor BLDC dan motor SRM sebagai pengembangan motor DC telah dipaparkan. Karakteristik ketiga motor hampir menyerupai. Nilai torka yang besar dari motor tersebut sangat sesuai untuk aplikasi pada sistem transportasi. Hasil simulasi dan pengujian menunjukkan bahwa motor BLDC dan 
motor SRM mampu menghasilkan torka besar saat awal pengasutan sehingga kecepatan dengan mudah dikendalikan.

\section{DAFTAR PUSTAKA}

Arefeen, M., S. (1998). Implementation of a Current Controlled Switched Reluctance Motor Drive Using TMS320F240, Application Report : SPRA282, Texas Instruments

Condit, R (2010). Brushed DC Motor Fundamentals, Microchip Tech. Inc

Dong, M. (2013). Research on Reduction the Torque Ripple in Switched Reluctance Motor, International Symposium on Computer, Consumer and Control

Emadi, A., Lee,Y. J. and Rajashekara, K. (2008). Power Electronics and Motor Drives in Electric, Hybrid Electric, and Plug-In Hybrid Electric Vehicles, IEEE Transc. on Industrial Electronics, Vol.55, No.6, 2237-2245

Hughes, A (2006). Electric Motors and Drives : undamentals, Types and Applications, Great Britain, Elsevier

Jain. A., K and Mohan, N. (2005). SRM Power Converter for Operation With High Demagnetization Voltage, IEEE Transc. on Industry Applications, Vol.41, No.5, pp.1224-1231Sanz, V. T., Sanguesa, J. A., Martinez, F. J.,
Garrido, P and Barja, J. M. M. (2018).

Enhancing the Charging Process of ElectricVehicles at Residential Homes, IEEE Access, Vo.6, 2287522888

Mahmoud, S., M., El-Sherif, M., Z., Abdel-Aliem, E., S. And Nashed, M., N., F. (2013).Studying Different Types of Power Converters Fed Switched Reluctance Motor, International Journal of Electronics and Electrical Engineering Vol. 1, No. 4, December, 2013

Riyadi, S. (2009). Diktat Penggerak Listrik, Unika Soegijapranata Semarang

Rodriguez, F. and Emadi, A. (2007). Novel Digital Control Technique for Brushless DC Motor Drives, IEEE Transc. on Industrial Electronics, Vol.54, No5, 2365-2373

Shao, J. (2006). An Improved Microcontroller-Based Sensorless Brushless DC (BLDC) Motor Drive for Automotive Applications, IEEE Transc. on Industry Applications, Vol.42, No5, 1216-1221

Yedamale, P. (2002). Speed Control of 3Phase Induction Motor Using PIC18 Microcontrollers, Microchip Tech. Inc

Yedamale, P. (2003). Brushless DC (BLDC) Motor Fundamentals, Microchip Tech. Inc 